[Article]

\title{
季铵盐型阳离子表面活性剂与牛血清白蛋白的相互作用
}

\author{
谢湖均 ${ }^{1, *}$ 刘程程 ${ }^{1}$ 孙 强 $^{1}$ 顾 青 $^{2, *} \quad$ 雷群芳 $^{3}$ 方文军 ${ }^{3, *}$ \\ ('浙江工商大学应用化学系, 杭州 310018; '浙江工商大学食品与生物工程学院, 杭州 310018; \\ 3浙江大学化学系, 杭州 310028)
}

\begin{abstract}
摘要: 本文合成并表征了三种不同烷基链长度的季铵盐型阳离子表面活性剂: $N$-十二烷基- $N$-(2-羟乙基)- $N$, $\mathrm{N}$-二甲基溴化铵 (DHDAB)、N-十四烷基- $N$-(2-差乙基) $-N, N$-二甲基溴化铵(THDAB)、N-十六烷基- $N$-(2-羊乙 基)- $N, N$-二甲基溴化铵(CHDAB)。采用苂光光谱法、紫外-可见光谱法、动态光散射法和等温滴定量热法对三 种表面活性剂与牛血清白蛋白(BSA)的相互作用进行研究。荧光光谱研究表明, 三种表面活性剂主要与 BSA 分子内的色氨酸残基发生相互作用, 导致蛋白质的构象发生变化, 且表面活性剂烷基链越长, 与 BSA 的相互 作用就越强。BSA 荧光猝灭的主要原因是静态猝灭, 紫外光谱实验同样验证了静态猝灭的存在。等温滴定量 热法结果表明低浓度的表面活性剂与 BSA 主要发生静电作用和疏水作用而放热。动态光散射结果表明高浓度 的表面活性剂会使BSA 结构被破坏。本文揭示了表面活性剂与 BSA 相互作用的机理, 为表面活性剂的广泛 应用提供了理论基础。
\end{abstract}

关键词: 表面活性剂; 牛血清白蛋白; 苂光猝灭; 动态光散射; 等温滴定量热

中图分类号: 0648

\section{The Interactions between Quaternary Ammonium Cationic Surfactants and Bovine Serum Albumin}

\author{
XIE Hu-Jun ${ }^{1, *} \quad$ LIU Cheng-Cheng ${ }^{1} \quad$ SUN Qiang ${ }^{1} \quad$ GU Qing ${ }^{2, *}$ \\ LEI Qun-Fang ${ }^{3} \quad$ FANG Wen-Jun ${ }^{3, *}$ \\ ('Department of Applied Chemistry, Zhejiang Gongshang University, Hangzhou 310018, P. R. China; \\ ${ }^{2}$ School of Food Science and Biotechnology, Zhejiang Gongshang University, Hangzhou 310018, P. R. China; \\ ${ }^{3}$ Department of Chemistry, Zhejiang University, Hangzhou 310028, P. R. China)
}

\begin{abstract}
UV-visible (UV-Vis) absorption spectroscopy, fluorescence spectroscopy (FL), dynamic light scattering (DLS) and isothermal titration calorimetry (ITC) were used to study the interactions between bovine serum albumin (BSA) and the three quaternary ammonium surfactants $N$-dodecyl- $N$-(2-hydroxyethyl)- $N, N$ dimethyl ammonium bromide (DHDAB), $\mathrm{N}$-tetradecyl- $\mathrm{N}$-(2-hydroxyethyl)- $\mathrm{N}, \mathrm{N}$-dimethyl ammonium bromide (THDAB) and $\mathrm{N}$-cetyl- $\mathrm{N}$-(2-hydroxyethyl)- $\mathrm{N}, \mathrm{N}$-dimethyl ammonium bromide (CHDAB). These surfactants quenched the intrinsic fluorescence of BSA, with longer alkyl chains resulting in more significant quenching. This was attributed to static quenching. Further evidence of static quenching was provided by UV-Vis absorption spectroscopy. The particle size of BSA was found to initially increase and then decrease with increasing surfactant concentration. The concentration of surfactant changed the type of interaction mode. This work revealed the mechanism and binding characteristics between surfactants and protein, and provides the basis
\end{abstract}

Received: July 18, 2016; Revised: September 22, 2016; Published online: September 23, 2016.

${ }^{*}$ Corresponding authors. XIE Hu-Jun, Email: hujunxie@gmail.com; Tel: +86-571-28008974. FANG Wen-Jun, Email: fwjun@zju.edu.cn.

GU Qing, Email: guqing2002@hotamail.com.

The project was supported by the National Natural Science Foundation of China (21203166, 21473157), Natural Science Foundation of Zhejiang Province, China (LY16B030001), and Food Science and Engineering the Most Important Discipline of Zhejiang Province, China (JYTsp2014111). 国家自然科学基金(21203166, 21473157), 浙江省自然科学基金(LY16B030001)与浙江省重中之重学科食品科学与工程(JYTsp2014111)资助项目 
for further applications of surfactants.

Key Words: Surfactants; Bovine serum albumin; Isothermal titration calorimetry

\section{Introduction}

Surfactants and proteins have attracted wide interest in the field of biology, food, medicine and cosmetics ${ }^{1-3}$. The structure, concentration, solvent, $\mathrm{pH}$, ionic strength and temperature have significant effects on the interactions between surfactants and proteins. The combination of surfactants with proteins often leads to the changes of conformations of proteins and surrounding microenvironment of certain amino acid residues. The main interaction types between ionic surfactants and proteins contain specific binding (electrostatic and hydrophobic interactions) and cooperative binding ${ }^{4-7}$. The influence of the alkyl chain length and types of surfactants on these interactions have been widely studied $^{8-11}$. In addition to traditional methods, such as surface tension, conductivity, electrochemical method, viscosity method, etc, some modern techniques containing UV-visible absorption spectroscopy, fluorescence spectroscopy, dynamic light scattering, circular dichroism spectroscopy, small-angle X-ray scattering, electron spin resonance spectroscopy and calorimetry were also employed to get a clear insight into the interactions between surfactants and proteins ${ }^{12-15}$.

Bovine serum albumin (BSA) is one of the most abundant proteins in mammalian plasma, capable of storing and transporting numerous endogenous and exogenous compounds ${ }^{16}$. Thus BSA is often employed as a protein model to study the interactions of protein with metal ions, drugs, dyes, surfactants, etc ${ }^{17-20}$. Study on the interaction mechanisms between proteins and surfactants, as well as the effects of different surfactants on the conformations of proteins, function and aggregation are of great significance for the development of relevant theory and practical applications.

In this manuscript, the interactions between quaternary ammonium surfactants and BSA have been studied by means of UVvisible (UV-Vis) absorption spectroscopy, fluorescence (FL) spectrometry, dynamic light scattering (DLS) and isothermal titration calorimetry (ITC) methods. The effect of alkyl chain length of surfactants on the interactions have also been discussed and explored. A series of important interaction parameters have been obtained to clarify the interaction mechanisms.

\section{Materials and methods}

\subsection{Materials}

BSA was purchased from Aladdin (nitrogen content $\geq 13.5 \%$ ); trihydroxy aminomethane (Tris) (purity $\geq 99.9 \%$ ); $\mathrm{HCl}$ (concentration $36 \%-38 \%$ ); $\mathrm{NaCl}$ (purity $\geq 99.5 \%$ ). Ultra-pure water was used for the preparation of all solutions. Three kinds of quaternary ammonium surfactants: $N$-dodecyl- $N$-(2-hydroxyethyl)$N, N$-dimethyl ammonium bromide (DHDAB), $N$-tetradecyl- $N$-(2hydroxyethyl)- $N, N$-dimethyl ammonium bromide (THDAB) and
$N$-cetyl- $N$ - (2-hydroxyethyl)- $N, N$-dimethyl ammoniu bromide (CHDAB) were synthesized in our laboratory.

The synthesis process is listed below.

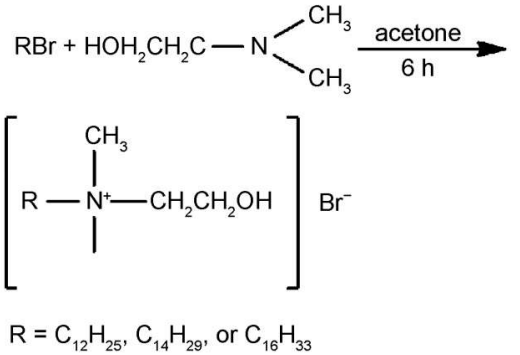

Infrared (IR) spectroscopy, ${ }^{1} \mathrm{H}$ nuclear magnetic resonance (NMR) analyses and elemental analysis (EA) of the synthesized surfactants were carried out on a NEXES 470 Fourier infrared spectrometer and Bruker Advance 2B $400 \mathrm{MHz}$ NMR spectrometer and Carlabo EA1110 elemental analyzer, respectively. The spectra and EA result are presented in the Supporting Information (Figs.S1-S3, Tables S1-S3, Supporting Information).

IR and NMR spectra of DHDAB are shown in Fig.S1 and EA result of DHDAB is listed in Table S1. The IR characteristic absorption peaks are as follows: $3238.3 \mathrm{~cm}^{-1}(\mathrm{OH}), 2917.0 \mathrm{~cm}^{-1}(\mathrm{C}-$ $\mathrm{H}), 1077.0 \mathrm{~cm}^{-1}(\mathrm{C}-\mathrm{N})$. The information obtained from the NMR spectra is as follows: $\left(\mathrm{CDCl}_{3}, 400 \mathrm{MHz}, 289 \mathrm{~K}\right) \delta_{\mathrm{H}}, 0.85(\mathrm{t}, J=6.8$ $\mathrm{Hz}, 3 \mathrm{H}), 1.24-1.34(\mathrm{~m}, 18 \mathrm{H}), 1.75(\mathrm{~m}, 2 \mathrm{H}), 3.35(\mathrm{~s}, 6 \mathrm{H}), 3.50(\mathrm{t}$, $J=8.4 \mathrm{~Hz}, 2 \mathrm{H}), 3.76(\mathrm{t}, J=4.6 \mathrm{~Hz}, 2 \mathrm{H}), 4.08-4.14(\mathrm{~m}, 2 \mathrm{H})$, $4.30-4.51(\mathrm{~m}, 1 \mathrm{H})$

IR and NMR spectra of THDAB are shown in Fig.S2 and EA result of THDAB is listed in Table S2. The IR characteristic absorption peaks are as follows: $3232.4 \mathrm{~cm}^{-1}(\mathrm{OH}), 2914.0 \mathrm{~cm}^{-1}(\mathrm{C}-$ $\mathrm{H}), 1060.5 \mathrm{~cm}^{-1}(\mathrm{C}-\mathrm{N})$. The chemical shifts of THDAB are as follows: $\left(\mathrm{CDCl}_{3}, 400 \mathrm{MHz}, 289 \mathrm{~K}\right) \delta_{\mathrm{H}}, 0.86(\mathrm{t}, J=6.8 \mathrm{~Hz}, 3 \mathrm{H})$, $1.24-1.33(\mathrm{~m}, 22 \mathrm{H}), 1.73(\mathrm{~m}, 2 \mathrm{H}), 3.34(\mathrm{~s}, 6 \mathrm{H}), 3.51(\mathrm{t}, J=8.4$ $\mathrm{Hz}, 2 \mathrm{H}), 3.78$ (t, $J=4.6 \mathrm{~Hz}, 2 \mathrm{H}), 4.08-4.12(\mathrm{~m}, 2 \mathrm{H}), 4.62-4.67$ $(\mathrm{m}, 1 \mathrm{H})$

IR and NMR spectra of CHDAB are shown in Fig.S3 and EA result of CHDAB is listed in Table S3. The IR characteristic absorption peaks are as follows: $3229.4 \mathrm{~cm}^{-1}(\mathrm{OH}), 2914.0 \mathrm{~cm}^{-1}(\mathrm{C}-$ $\mathrm{H}), 1090.2 \mathrm{~cm}^{-1}(\mathrm{C}-\mathrm{N})$. The chemical shifts of CHDAB are as follows: $\left(\mathrm{CDCl}_{3}, 400 \mathrm{MHz}, 289 \mathrm{~K}\right) \delta_{\mathrm{H}}, 0.86(\mathrm{t}, J=6.6 \mathrm{~Hz}, 3 \mathrm{H})$, $1.21-1.31(\mathrm{~m}, 26 \mathrm{H}), 1.72-1.77(\mathrm{~m}, 2 \mathrm{H}), 3.34(\mathrm{~s}, 6 \mathrm{H}), 3.53(\mathrm{t}, J=$ $8.2 \mathrm{~Hz}, 2 \mathrm{H}), 3.72(\mathrm{t}, J=4.6 \mathrm{~Hz}, 2 \mathrm{H}), 4.09-4.13(\mathrm{~m}, 2 \mathrm{H}), 4.31-$ $4.53(\mathrm{~m}, 1 \mathrm{H})$.

The thermogravimetric analysis (TGA) curves are presented in Figs.S4-S6 (Supporting Information). TGA results showed that the decomposition temperature is increased with the increase of alkyl chain length of surfactants

Tris- $\mathrm{HCl}$ buffer solution $\left(\mathrm{pH}=7.0\right.$, containing $0.1 \mathrm{~mol} \cdot \mathrm{L}^{-1}$ 
$\mathrm{NaCl}$ to maintain ionic strength) was prepared, which was used to prepare $50 \mu \mathrm{mol} \cdot \mathrm{L}^{-1} \mathrm{BSA}$ solution and a series of different concentrations of surfactant solutions.

\subsection{Spectral measurements}

The fluorescence spectra were obtained using a RF-5301PC fluorescence spectrophotometer (Shimadzu, Japan) equipped with a $1.0 \mathrm{~cm}$ path length quartz cell. The excitation and emission wavelengths of BSA were monitored at 280 and $350 \mathrm{~nm}$, respectively. The excitation and emission slits are $3 \mathrm{~nm}$. Synchronous fluorescence spectra acquired by fixing the difference of excitation and emission wavelength $(\Delta \lambda)$ at 15 and $60 \mathrm{~nm}$. All samples were thermostated at $298 \mathrm{~K}$.

The UV-visible absorption spectra were measured on a UV2450 ultraviolet-visible spectrophotometer (Shimadzu, Japan) at $298 \mathrm{~K}$. The absorption spectra were recorded in the wavelength range from 250 to $350 \mathrm{~nm}$, and a $1.0 \mathrm{~cm}$ path length quartz cell was used for the absorbance measurements.

\subsection{DLS measurements}

DLS experiments were performed using a Z-sizer nano ZS (Malvern, UK) at $298 \mathrm{~K}$. The concentration of BSA was 5.0 $\mu \mathrm{mol} \cdot \mathrm{L}^{-1}$ and all BSA-surfactants mixed solutions went through $0.22 \mu \mathrm{m}$ micro membrane filter twice. For each concentration of BSA-surfactant mixed solution, particle size was measured three times and the average values are reported.

\subsection{ITC determination}

ITC data were collected on a high precision microcalorimeter VP-ITC (Micro Co., USA). The enthalpy changes $(\Delta H)$ were obtained by injecting surfactant into the $1.4 \mathrm{~mL}$ calorimetric cell, in the absence and presence of BSA in Tris- $\mathrm{HCl}$ buffer solution at $\mathrm{pH}=7.0$. The experiments were performed by one injection of 10 $\mu \mathrm{L}$ with a $240 \mathrm{~s}$ interval between each injection and the temperature was set to $298 \mathrm{~K}$. The surfactant solution in the cell was stirred at $270 \mathrm{r} \cdot \mathrm{min}^{-1}$.

\section{Results and discussion}

\subsection{BSA-surfactants interactions by fluorescence spectrometry}

Previous studies suggested that the chromophores of BSA including tryptophan (Trp), tyrosine (Tyr) and phenylalanine (Phe) can launch strong intrinsic fluorescence ${ }^{21,22}$. In present experiments, the excitation and emission wavelengths of BSA were monitored at 280 and $340 \mathrm{~nm}$, respectively (Fig.1). The results showed that three surfactants can lead to the fluorescence quenching, similar to other cationic surfactants ${ }^{23}$. With the increase of the concentration of surfactant solutions, it showed good fluorescence quenching to BSA, and the blue shift of maximum emission wavelength of BSA was also observed, which were attributed to the unfold of the BSA structure. Previous researches reported that the interaction information involving the quenching mechanism, binding constant and binding sites between BSA and surfactants can be obtained by analyzing the fluorescence spec$\operatorname{tra}^{24}$. On the basis of the fluorescence emission spectra of BSAsurfactants mixed systems, fluorescence intensity ratio $\left(I_{0} / I\right)$ can

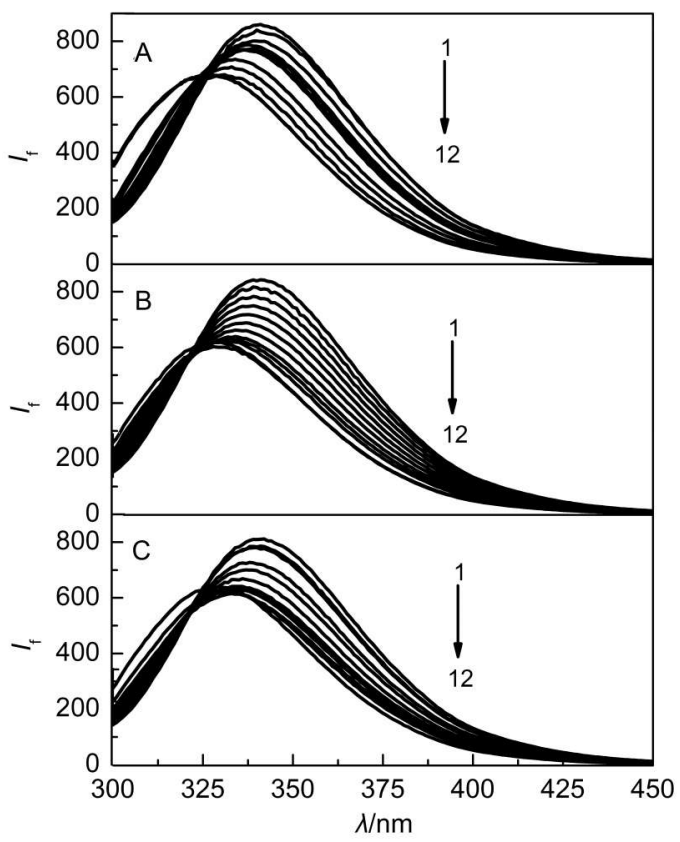

Fig.1 Fluorescence emission spectra of BSA $\left(5.0 \mu \mathrm{mol} \cdot \mathrm{L}^{-1}\right)$ in the surfactants/Tris-HCl buffer systems $(T=298 \mathrm{~K})$

(A) concentration of $\mathrm{DHDAB} /\left(\mathrm{mol} \cdot \mathrm{L}^{-1}\right)$ : (1) 0 ; (2) $1.8 \times 10^{-5}$; (3) $3.6 \times 10^{-5}$; (4) $4.8 \times 10^{-5}$; (5) $6.0 \times 10^{-5}$; (6) $8.0 \times 10^{-5}$; (7) $1.0 \times 10^{-4}$; (8) $1.4 \times 10^{-4}$; (9) $1.8 \times 10^{-4}$; (10) $2.2 \times 10^{-4}$; (11) $2.6 \times 10^{-4}$; (12) $3.0 \times 10^{-4}$, (B) concentration of $\mathrm{THDAB} /\left(\mathrm{mol} \cdot \mathrm{L}^{-1}\right)$ : (1) 0 ; (2) $1.2 \times 10^{-5}$; (3) $2.0 \times 10^{-5}$; (4) $3.0 \times 10^{-5}$; (5) $4.0 \times 10^{-5}$; (6) $6.0 \times 10^{-5}$; (7) $8.0 \times 10^{-5}$; (8) $1.2 \times 10^{-4}$; (9) $1.6 \times 10^{-4}$; (10) $2.0 \times 10^{-4}$; (11) $2.5 \times 10^{-4}$; (12) $3.0 \times 10^{-4}$, (C) concentration of CHDAB/ $\left(\mathrm{mol} \cdot \mathrm{L}^{-1}\right.$ ): (1) 0 ; (2) $6.0 \times 10^{-6}$; (3) $1.2 \times 10^{-5}$; (4) $1.8 \times 10^{-5}$; (5) $2.4 \times 10^{-5}$; (6) $3.0 \times 10^{-5}$; (7) $3.6 \times 10^{-5}$; (8) $4.2 \times 10^{-5}$; (9) $6.0 \times 10^{-5}$; (10) $1.0 \times 10^{-4}$; (11) $2.0 \times 10^{-4}$; (12) $3.0 \times 10^{-4}$. All the concentrations of three surfactants are lower than critical micelle concentration $(\mathrm{CMC})$, which were measured by

ITC experiments later. $I_{\mathrm{f}}$ : fluorescence intensity

be obtained by the addition of different concentrations of surfactants, where $I_{0}$ and $I$ are the fluorescence intensities of BSA in the absence and presence of quenchers (surfactants), respectively.

As shown in Fig.2, the fluorescence quenching effect of three surfactants on BSA is related to the alkyl chain length of surfactants, and the surfactants with long alkyl chain length have strong fluorescence quenching effect on BSA. The isoelectric point of BSA was 4.9, thus the BSA carries negative charge at the $\mathrm{pH}$ value of 7.0. As three kinds of quaternary ammonium surfactants carries positive charge, electrostatic interactions between surfactants and BSA play an important role in the mixed systems $\mathrm{s}^{25,26}$. Another important role is the hydrophobic interactions between the hydrophobic carbon chains of the surfactants and the hydrophobic groups of the protein. Three surfactants have same structures of cationic quaternary ammonium moiety and show similar electrostatic interactions with BSA. Thus the main factors affecting the interactions between different surfactants and BSA are hydrophobic interactions. It is interesting to note that a long length of alkyl chain of surfactant can lead to the strong hydrophobic interactions. Therefore, the hydrophobic interaction strength of surfactants follows the order. CHDAB $>$ THDAB $>$ DHDAB. The curve of $I_{0} / I-$ surfactant concentration $(C)$ rela- 


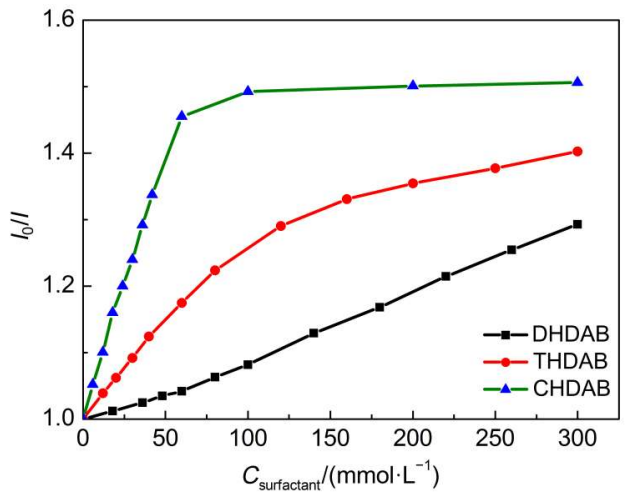

Fig.2 Fluorescence intensity ratio $\left(I_{0} / I\right)$ versus concentration of three surfactants $(C)$

tionship for $\mathrm{CHDAB}$ with the longest alkyl chain has an inflection point, after which it changes slowly to the platform; the curve of $I_{0} / I-C$ relationship for THDAB also has a inflection point, and after the inflection point the increase of $I_{0} / I$ tends to be gentle; the curve of $I_{0} / I-C$ surfactant relationship for DHDAB with the shortest alkyl chain does not show a inflection point. The inflexion point, especially with the emergence of the platform, indicates that the combination of surfactants and BSA tends to be complete or the aggregation of surfactants on the surface of BSA gradually tends to be saturated ${ }^{27}$.

Fluorescence quenching contains static and dynamic quenching $^{28-31}$, and the static quenching is caused by the formation of a non-fluorescence complex between quencher and fluorophore, while dynamic quenching is caused by collisional encounters between quencher and fluorophore. The fluorescence data were further analyzed via Stern-Volmer equation ${ }^{32,33}$.

$$
I_{0} / I=1+K_{\mathrm{sv}} C=1+K_{\mathrm{q}} T_{\mathrm{o}} C
$$

where $I_{0}$ and $I$ are the fluorescence intensity of BSA in the absence and presence of quencher, respectively. $T_{0}$ is the average lifetime of BSA $\left(T_{\mathrm{o}}=10^{-8} \mathrm{~s}\right)^{34} . K_{\mathrm{q}}$ stands for the quenching rate constant of the biological macromolecule; $K_{\mathrm{sv}}$ is the Stern-Volmer quenching constant.

Fig. 3 shows the Stern-Volmer plots of the surfactants interactions with BSA at 289 and $298 \mathrm{~K}$, and the Stern-Volmer quenching constants of three interactions can be found in Table 1. For the lowconcentration linear region of the surfactants, the fluorescence quenching effect of surfactants on the BSA is well accord with the Stern-Volmer equation. In Table $1, K_{\mathrm{sv}}$ is inversely correlated with

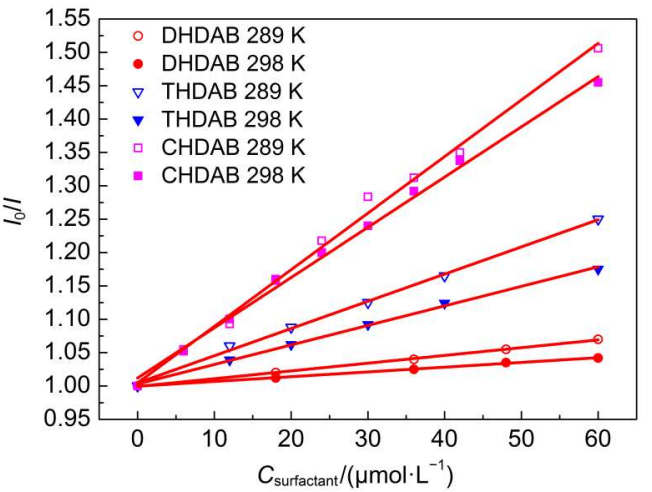

Fig.3 Stern-Volmer plots of interactions of three surfactants with BSA at 289 and $298 \mathrm{~K}$

temperature and $K_{\mathrm{q}}$ is much greater than the value of the maximum scatter collision quenching constant of $2.0 \times 10^{10} \mathrm{~L} \cdot \mathrm{mol}^{-1} \cdot \mathrm{s}^{-135,36}$, thus this quenching process is static quenching ${ }^{37}$.

The following double-reciprocal formula was used to deal with the experimental data for static quenching interaction ${ }^{38}$.

$\lg \left[\left(I_{0}-I\right) / I\right]=\lg K_{\mathrm{A}}+n \lg C$

where $K_{\mathrm{A}}$ is the binding constant between BSA and quencher; $n$ is the number of binding sites. Fig. 4 shows the double-reciprocal curve of surfactants interacting with BSA at 289 and $298 \mathrm{~K}$, and the binding constant $K_{\mathrm{A}}$ and binding sites $n$ are listed in Table 1 .

For different surfactants, both quenching $\left(K_{\mathrm{sv}}\right)$ and binding $\left(K_{\mathrm{A}}\right)$ constants follow the order: CHDAB $>$ THDAB $>$ DHDAB. The results indicated that the long alkyl chains of surfactants have the stronger binding interactions with BSA. The numbers of binding sites of three surfactants with BSA at 289 and $298 \mathrm{~K}$ are close to 1.

Synchronous fluorescence spectroscopy can give information about the change of protein microenvironment. A shift of the maximum emission wavelength is involved in the alteration of the polarity in the microenvironment around the chromophore ${ }^{39} . \Delta \lambda$ represents the value of the difference between excitation and emission wavelengths. When the values of $\Delta \lambda$ are stabilized at 15 and $60 \mathrm{~nm}$, the synchronous fluorescence shows the characteristics of tyrosine and tryptophan residues, respectively ${ }^{40}$. Since the maximum emission wavelength of residues is related to its environmental polarity, the change of the protein conformation is determined by the analysis of emission wavelength change ${ }^{41}$. When $\Delta \lambda$ was set at $15 \mathrm{~nm}$, the fluorescence intensity decreased obviously with the increase of surfactant concentrations (Figs.5A-

Table 1 Binding constant $\left(K_{\mathrm{A}}\right)$, quenching constant $\left(K_{\mathrm{sv}}\right)$ and binding sites $(n)$ of surfactants with BSA at 289 and $298 \mathrm{~K}$

\begin{tabular}{|c|c|c|c|c|c|c|c|}
\hline \multirow{2}{*}{ Surfactant } & \multirow{2}{*}{$T / \mathrm{K}$} & \multicolumn{3}{|c|}{ Stern-Volmer } & \multicolumn{3}{|c|}{ Lineweaver-Burk } \\
\hline & & $R^{\mathrm{a}}$ & $K_{\mathrm{sv}} /\left(\mathrm{L} \cdot \mathrm{mol}^{-1}\right)$ & $K_{\mathrm{q}} /\left(\mathrm{L} \cdot \mathrm{mol}^{-1} \cdot \mathrm{s}^{-1}\right)$ & $R^{a}$ & $K_{\mathrm{A}} /\left(\mathrm{L} \cdot \mathrm{mol}^{-1}\right)$ & $n$ \\
\hline \multirow[t]{2}{*}{ DHDAB } & 289 & 0.999 & $1.16 \times 10^{3}$ & $1.16 \times 10^{11}$ & 0.999 & $1.68 \times 10^{3}$ & 1.039 \\
\hline & 298 & 0.998 & $0.71 \times 10^{3}$ & $0.71 \times 10^{11}$ & 0.997 & $1.23 \times 10^{3}$ & 1.056 \\
\hline \multirow[t]{2}{*}{ THDAB } & 289 & 0.997 & $4.08 \times 10^{3}$ & $4.08 \times 10^{11}$ & 0.999 & $2.19 \times 10^{3}$ & 0.936 \\
\hline & 298 & 0.997 & $2.93 \times 10^{3}$ & $2.93 \times 10^{11}$ & 0.999 & $1.71 \times 10^{3}$ & 0.944 \\
\hline \multirow[t]{2}{*}{ CHDAB } & 289 & 0.995 & $8.48 \times 10^{3}$ & $8.48 \times 10^{11}$ & 0.993 & $8.03 \times 10^{3}$ & 0.993 \\
\hline & 298 & 0.995 & $7.53 \times 10^{3}$ & $7.53 \times 10^{11}$ & 0.997 & $4.26 \times 10^{3}$ & 0.939 \\
\hline
\end{tabular}

${ }^{\mathrm{a}} R$ is the correlation coefficient. 


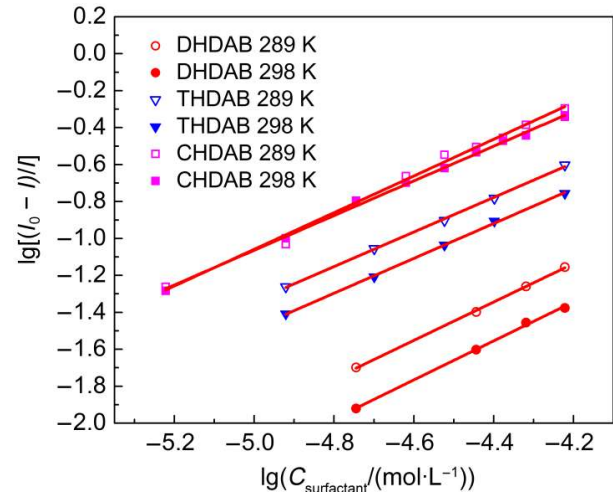

Fig.4 Double-reciprocal curve of interactions of three surfactants with BSA at 289 and $298 \mathrm{~K}$

7A); when $\Delta \lambda$ was set at $60 \mathrm{~nm}$, the fluorescence intensity increased significantly with the increase of surfactants concentrations (Figs.5B to 7B). In addition, the maximum emission wavelength showed a blue shift, which indicated that the microenvironment around Trp residues was disturbed and the hydrophobicity was increased in the presence of surfactants ${ }^{42}$. The fluorescence intensity of Trp residues was significantly higher than that of Tyr residues, indicating that the main contribution of the intrinsic fluorescence of BSA comes from Trp residues, thus three surfactants mainly interact with Trp residues of BSA.
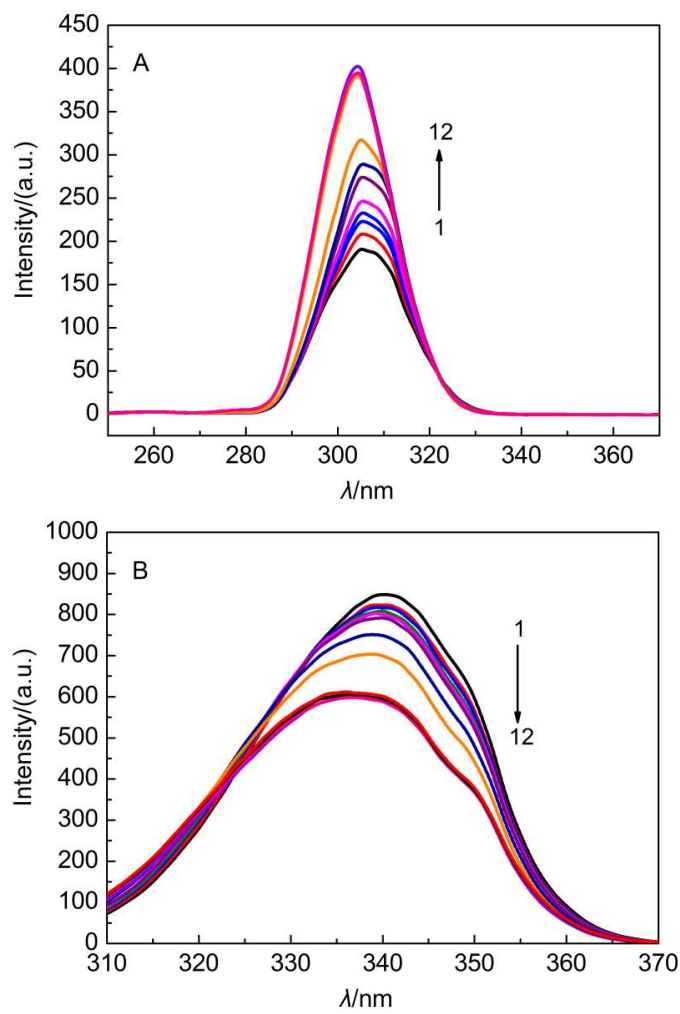

Fig.5 Synchronous fluorescence spectra of BSA in the DHDAB/Tris-HCl buffer system

(A) $\Delta \lambda=15 \mathrm{~nm}$; (B) $\Delta \lambda=60 \mathrm{~nm}$. concentration of DHDAB $/\left(\mathrm{mol}^{\circ} \cdot \mathrm{L}^{-1}\right)$ : (1) 0 ; (2) $1.8 \times 10^{-5}$; (3) $3.6 \times 10^{-5}$; (4) $4.8 \times 10^{-5}$; (5) $6.0 \times 10^{-5}$; (6) $8.0 \times 10^{-5}$; (7) $1.6 \times$ $10^{-4} ;$ (8) $2.4 \times 10^{-4}$; (9) $3.2 \times 10^{-4} ;$ (10) $4.0 \times 10^{-4}$; (11) $5.2 \times 10^{-4}$; (12) $6.4 \times 10^{-4}$
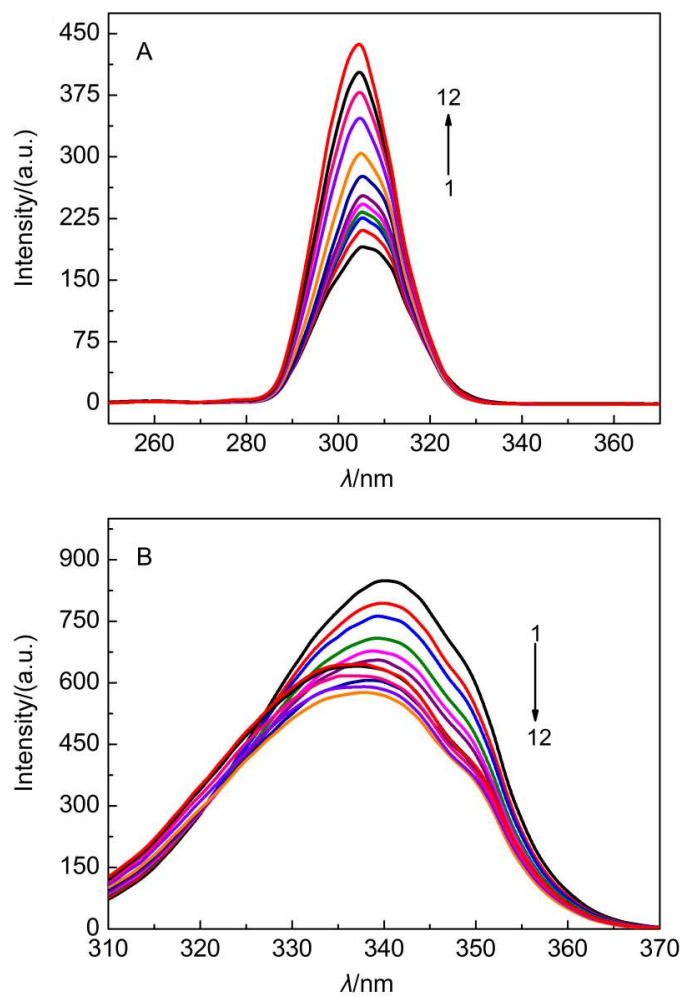

Fig.6 Synchronous fluorescence spectra of BSA in the THDAB/Tris-HCl buffer system

(A) $\Delta \lambda=15 \mathrm{~nm}$; (B) $\Delta \lambda=60 \mathrm{~nm}$. concentration of THDAB/(mol $\left.\cdot \mathrm{L}^{-1}\right)$ : (1) 0 ; (2) $1.2 \times 10^{-5}$; (3) $2.0 \times 10^{-5}$; (4) $3.0 \times 10^{-5}$; (5) $4.0 \times 10^{-5}$; (6) $6.0 \times 10^{-5}$; (7) $8.0 \times$ $10^{-5}$; (8) $1.2 \times 10^{-4}$; (9) $1.6 \times 10^{-4}$; (10) $2.0 \times 10^{-4}$; (11) $3.2 \times 10^{-4}$; (12) $4.4 \times 10^{-4}$

\subsection{BSA-surfactants interactions by UV-Vis absorption spectroscopy}

Further evidence of static quenching of BSA upon addition of surfactants was provided by UV-visible absorption spectrum data. Collisional encounters between quencher and fluorophore have no effect on the absorption spectra of protein, and they only affect the excited states of the fluorophores. In contrast, the formation of a ground-state complex between quencher and fluorophore can influence on the absorption spectra ${ }^{43,44}$. Fig. 8 shows the UV-visible absorption spectra of BSA in surfactants/Tris- $\mathrm{HCl}$ buffer systems. As shown in Fig.8, the intensity of absorption spectra decreases gradually with the increase of surfactant (DHDAB, THDAB and $\mathrm{CHDAB}$ ) concentrations from 1 to 6 , which indicates that surfactants and protein may form complex, and also proves that the fluorescence quenching of BSA is caused by static quenching. While three surfactant solutions without BSA have no absorption peak near $280 \mathrm{~nm}$.

\subsection{BSA-surfactants interactions by DLS}

As shown in Fig.9, the initial particle size of BSA (5.0 $\mu \mathrm{mol} \cdot$ $\left.\mathrm{L}^{-1}\right)$ in the Tris- $\mathrm{HCl}$ buffer solution $(\mathrm{pH}=7.0)$ at $298 \mathrm{~K}$ is about $7.58 \mathrm{~nm}$. The particle size of surfactant-BSA complexes gradually grows with the increase of the surfactants concentrations. The particle size of three surfactants- BSA complexes at low concentration (less than $1 \mathrm{mmol} \cdot \mathrm{L}^{-1}$ ) follows the order: $\mathrm{CHDAB}>$ THDAB $>$ DHDAB. Moreover, the surfactants with longer alkyl 

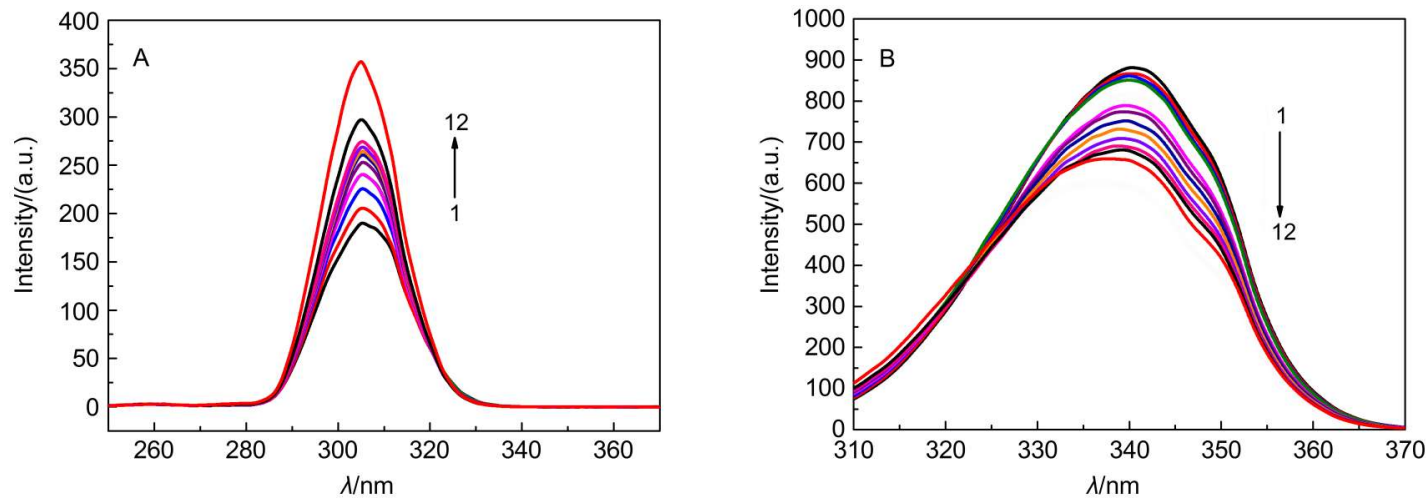

Fig.7 Synchronous fluorescence spectra of BSA in the CHDAB/Tris-HCl buffer system

(A) $\Delta \lambda=15 \mathrm{~nm}$; (B) $\Delta \lambda=60 \mathrm{~nm}$. concentration of CHDAB/(mol $\left.\cdot \mathrm{L}^{-1}\right)$ : (1) 0 ; (2) $6.0 \times 10^{-6}$; (3) $1.2 \times 10^{-5}$; (4) $1.8 \times 10^{-5} ;$ (5) $2.4 \times 10^{-5}$;

(6) $3.0 \times 10^{-5}$; (7) $3.6 \times 10^{-5}$; (8) $4.2 \times 10^{-5}$; (9) $4.8 \times 10^{-5}$; (10) $6.0 \times 10^{-5}$; (11) $1.0 \times 10^{-4}$; (12) $2.0 \times 10^{-4}$

chain interact much stronger with BSA. As the concentrations of DHDAB, THDAB and CHDAB reach to $6,2.56$ and $1.28 \mathrm{mmol} \cdot$ $\mathrm{L}^{-1}$, it shows the largest particle size of surfactant-BSA complexes with the values of $10.76,11.30$ and $11.42 \mathrm{~nm}$, respectively. As the surfactant concentrations continue to increase, the particle size of surfactant-BSA complexes began to decline, and finally the particle diameters fall below the initial value, which indicates that the geometry of BSA has changed.

\subsection{BSA-surfactants interactions by ITC}

We then determined the $\mathrm{CMC}$ values of three surfactants in

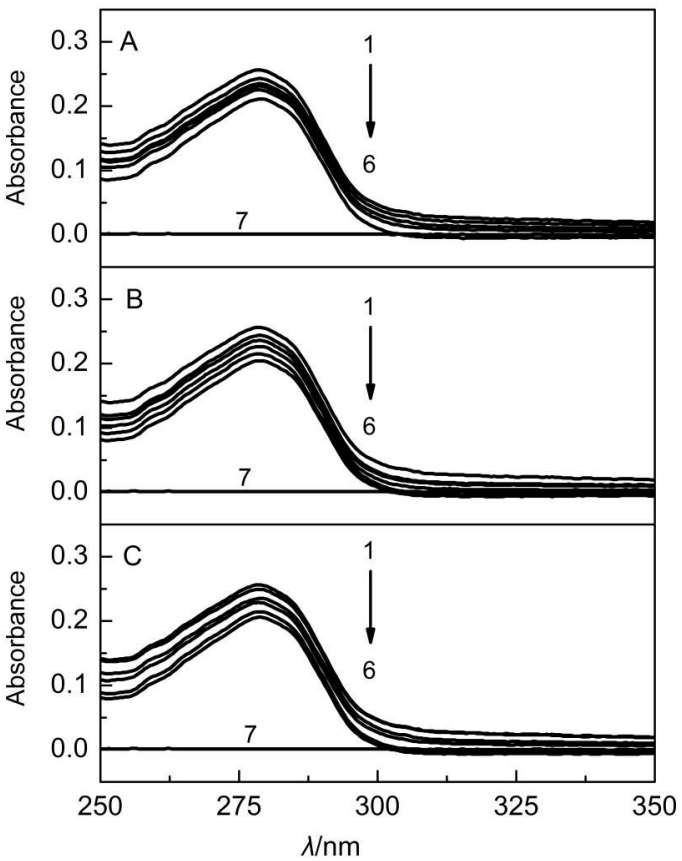

Fig.8 UV-visible spectra of BSA $\left(5.0 \mu \mathrm{mol} \cdot \mathrm{L}^{-1}\right)$ in surfactants/Tris-HCl buffer systems $(T=298 \mathrm{~K})$

(A) concentration of DHDAB/(mol $\left.\cdot \mathrm{L}^{-1}\right)$ : (1) 0 ; (2) $3.6 \times 10^{-5}$; (3) $6.0 \times 10^{-5}$; (4) $1.0 \times 10^{-4}$; (5) $1.8 \times 10^{-4}$; (6) $2.6 \times 10^{-4}$; (7) $5.0 \times 10^{-6}$ without BSA, (B) concentration of THDAB $/\left(\mathrm{mol} \cdot \mathrm{L}^{-1}\right)$ : (1) 0 ; (2) $2.0 \times 10^{-5}$; (3) $4.0 \times 10^{-5}$; (4) $8.0 \times 10^{-5}$; (5) $1.6 \times 10^{-4}$; (6) $2.5 \times 10^{-4}$; (7) $5.0 \times 10^{-6}$ without BSA,

(C) concentration of $\mathrm{CHDAB} /\left(\mathrm{mol} \cdot \mathrm{L}^{-1}\right)$ : (1) 0 ; (2) $1.2 \times 10^{-5}$; (3) $2.4 \times 10^{-5}$; (4) $3.6 \times 10^{-5}$; (5) $6.0 \times 10^{-5}$; (6) $2.0 \times 10^{-4}$; (7) $5.0 \times 10^{-6}$ without BSA buffer solution by isothermal titration calorimetry (ITC) ${ }^{45-47}$. Fig. 10 (A, C, E) displays the representative heat flow profiles as a function of time, which is related to $10 \mu \mathrm{L}$ aliquot injections of three surfactants $\left(80,10\right.$ and $\left.1 \mathrm{mmol} \cdot \mathrm{L}^{-1}\right)$ into the cell containing Tris- $\mathrm{HCl}$ buffer solution ( $\mathrm{pH}=7.0, T=298 \mathrm{~K}$ ). The enthalpy changes of surfactants $(\Delta H)$ as a function of surfactants concentration are shown in Fig.10(B, D, F). $\Delta H$ was calculated by integrating each heat flow peak with time. According to Fig.10(A, $\mathrm{C}, \mathrm{E})$, when the first surfactant aliquots are added into the cell, intense endothermic peaks are observed due to the demicellization of surfactants. It is known that the concentrations of three surfactants in the cell at the first injections remain below the CMC. Upon the increase of surfactant concentration in the cell, the intensity of the endothermic peaks decreases drastically owing to the formation of micelles in solution. Further increase of surfactants concentration above the $\mathrm{CMC}$, the intensity of the endothermic peaks keeps constant resulting from the micelle dilution. The $\mathrm{CMC}$ values of three surfactants in Tris- $\mathrm{HCl}$ buffer solution were determined from the first derivative of the $\Delta H$ curve against surfactant concentration. The CMC values of DHDAB, THDAB and $\mathrm{CHDAB}$ are around $6.44,0.58$ and $0.06 \mathrm{mmol} \cdot \mathrm{L}^{-1}$ (Fig.10(B, $\mathrm{D}, \mathrm{F})$ ), which indicates that the $\mathrm{CMC}$ values of surfactants increase with the increase of alkyl chain length of surfactants.

In the ITC experiments, the blank experiments involving the

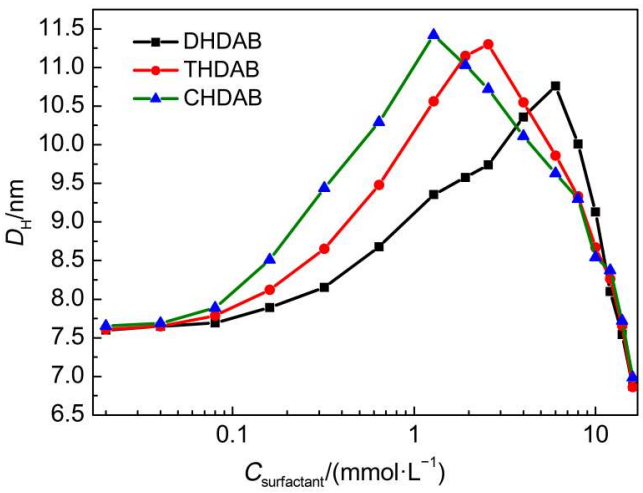

Fig.9 Hydrodynamic diameter $\left(D_{\mathrm{H}}\right)$ of BSA in surfactants/Tris-HCl buffer systems at $298 \mathrm{~K}$ 

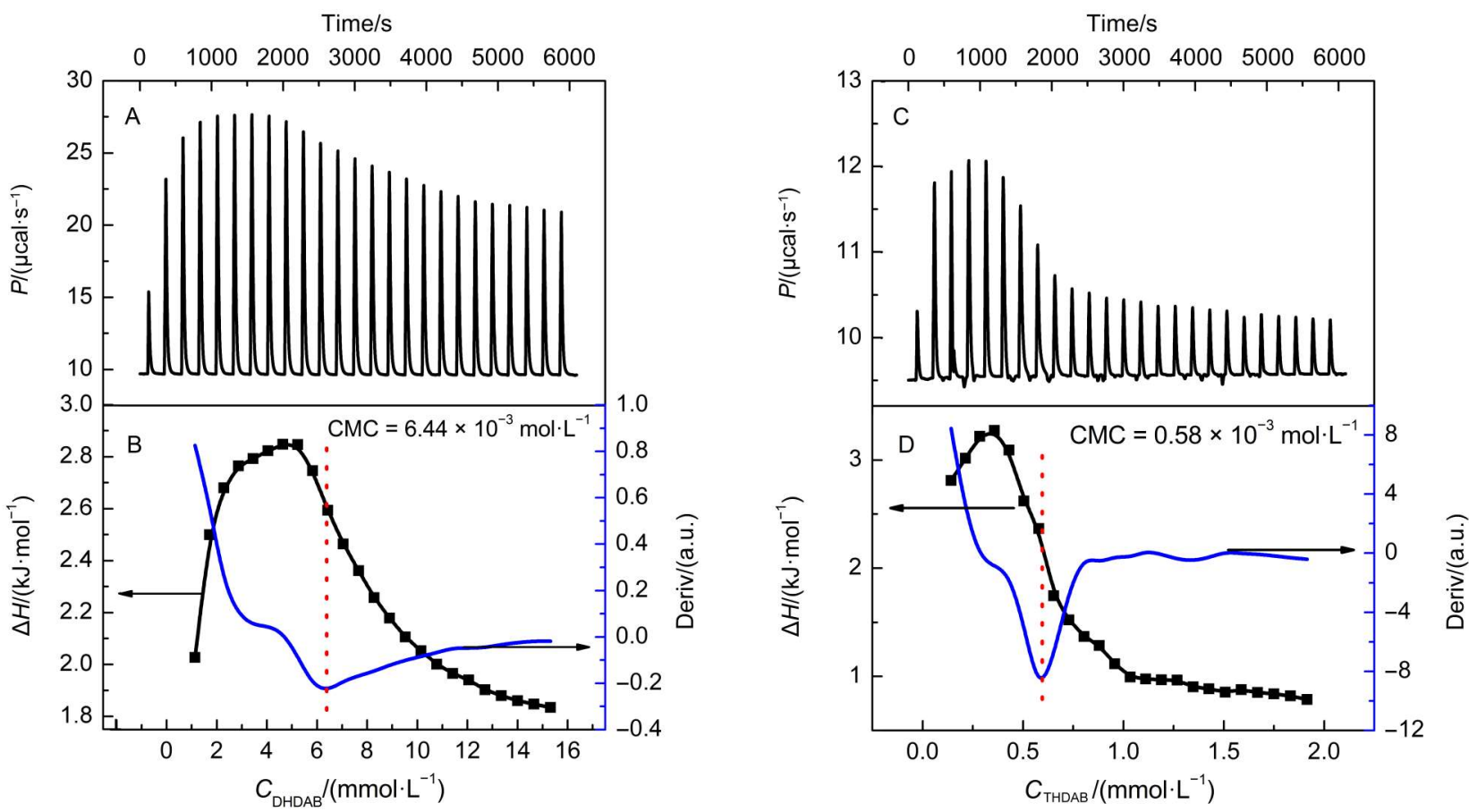

Time/s

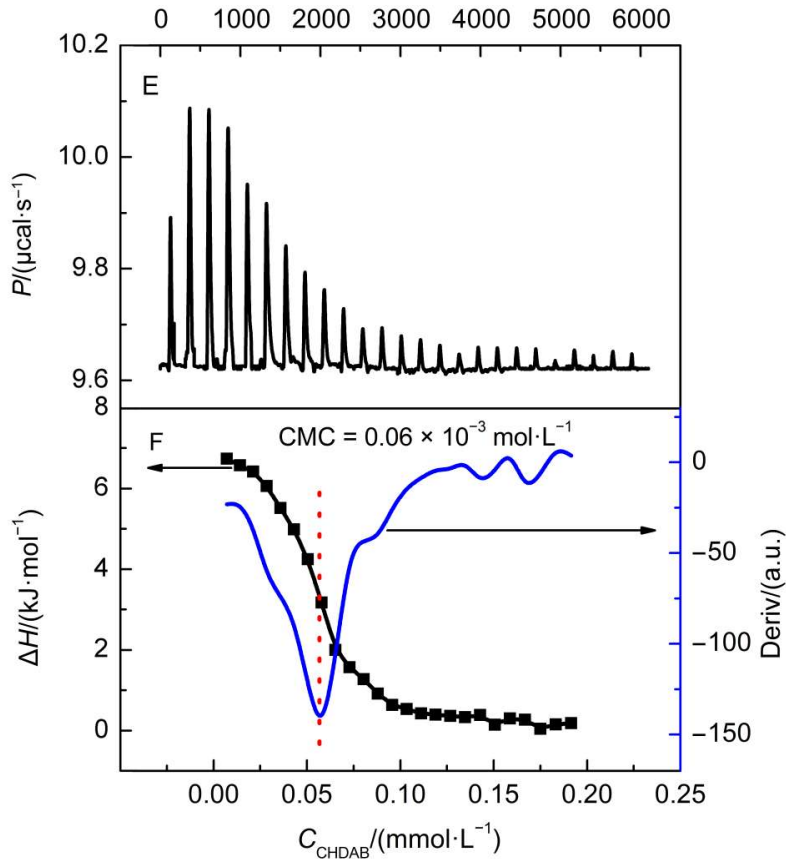

Fig.10 Control experiment showing typical calorimetric titration curves for three surfactants dilution in buffer solution Plots of heat flow $(P)$, as a function of time, for injections of $10 \mu \mathrm{L}$ aliquots of DHDAB, THDAB and CHDAB $\left(80,10\right.$ and $\left.1 \mathrm{mmol} \cdot \mathrm{L}^{-1}\right)$ in the reaction cell $(1.4 \mathrm{~mL})$, containing Tris- $\mathrm{HCl}$ buffer solution, in $240 \mathrm{~s}$ intervals, at $\mathrm{pH} 7.0$ and $298 \mathrm{~K}$ (A, C, E). Plots of enthalpy change of surfactants $(\Delta H$ ), as a function of surfactants concentration (B, D, F). The surfactants CMC value was determined from the derivative $\Delta H$ curve (Deriv) versus surfactants concentration plots (the blue curve).

The minimum is taken as the CMC. $1 \mathrm{cal}=4.1868 \mathrm{~J}$. color online

surfactants and BSA solutions titration into the buffer solution were separately carried out, which can offset the effects related to the dissociation of surfactant micelles and the dilution of the surfactant micelles. $\Delta H$ was then obtained via deducting the dilution effect of surfactants and BSA solution during titration (Fig.11(B, D, F)). The concentrations of surfactants in these ITC experiments are far greater than that of CMC. Several factors may mediate the interaction enthalpy $\Delta H$ between surfactants and BSA, including the dissociation of surfactant micelles, the dilution of the surfactant micelles, the interaction between surfactant monomer and BSA, the interaction between micelles and BSA, and the break of the secondary structure of $\mathrm{BSA}^{48}$.

Heat flow and interaction enthalpy for surfactants solution titration into BSA solution are shown in Fig.11. As shown in 
Fig.11A, the interaction between DHDAB and BSA is an endothermic process in the experimental concentration range. In Fig. $11 \mathrm{C}$, the interaction process between THDAB and BSA was initially exothermic, and then endothermic with the increase of concentration of THDAB. For Fig.11E, the interaction between CHDAB and BSA is an exothermic process. Fig.11(B, D, F) reveal that when the concentrations of three surfactants are less than $\mathrm{CMC}$, the reaction enthalpy between surfactant and BSA is gradually increased with the increase of concentration of three surfactants. In the case of DHDAB, when the concentration of DHDAB goes beyond $\mathrm{CMC}$, the reaction enthalpy decreases until almost zero. In the case of THDAB and CHDAB, when the concentration of surfactant goes beyond $\mathrm{CMC}$, the reaction enthalpy tends to keep constant.

The BSA carries negative charge at the $\mathrm{pH}$ value of 7.0, thus the electrostatic interaction caused mainly by the polar positive groups
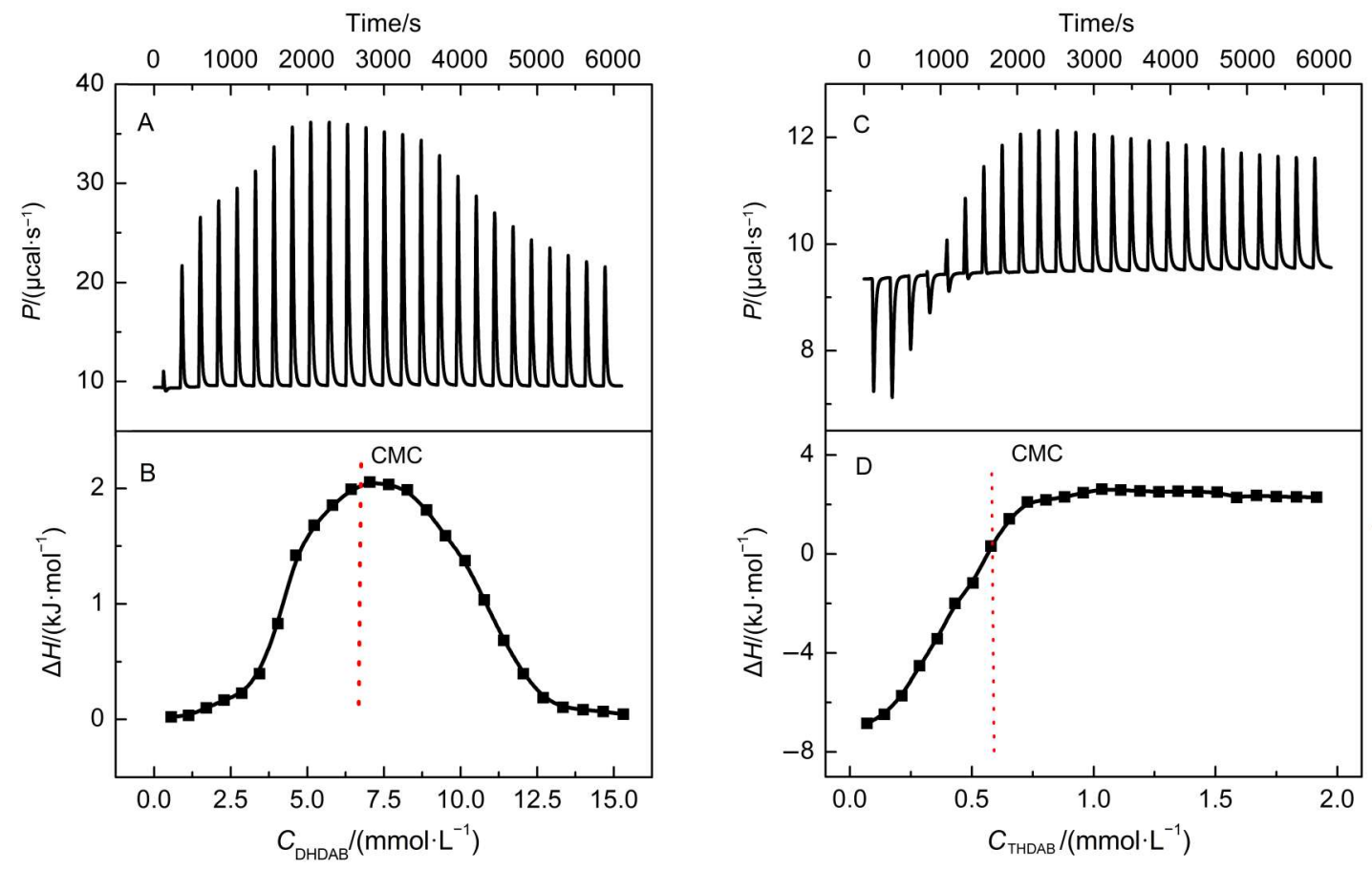

Time/s

$0 \quad 1000 \quad 20003000 \quad 4000 \quad 50006000$

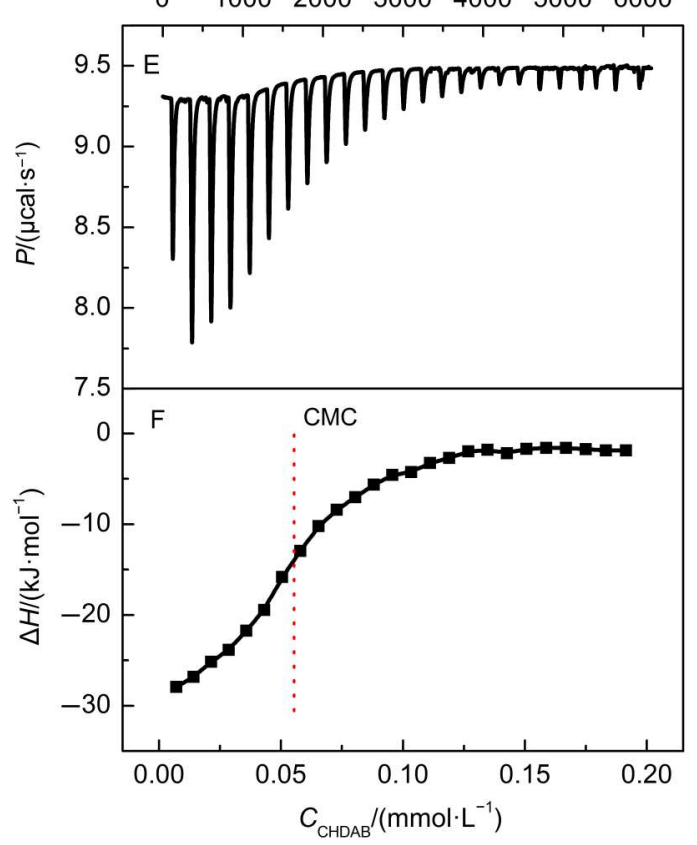

Fig.11 Heat flow and interaction enthalpy for three surfactants solution titration to $5.0 \mu \mathrm{mol} \cdot \mathrm{L}^{-1} \mathrm{BSA}$ solution in pH 7.0 Tris-HCl buffer solution against the concentration of surfactant at $298 \mathrm{~K}$ The titrated concentration of DHDAB, THDAB and CHDAB solution are 80,10 and $1 \mathrm{mmol} \cdot \mathrm{L}^{-1}$. 
of surfactants and amino acid residues is an exothermic process. While the hydrophobic interaction between the hydrophobic carbon chains of surfactants and the hydrophobic groups of the protein is an exothermic process. The destruction of the hydrated layer structure of polar groups and BSA molecules is an endothermic process $^{49}$. In addition, the alternation of secondary structure of BSA is an endothermic process ${ }^{50}$.

The initial titration concentrations of DHDAB, THDAB and CHDAB solution in syringe are 80,10 and $1 \mathrm{mmol} \cdot \mathrm{L}^{-1}$, respectively. In the case of high titration concentration of surfactant (Fig.11A), the exothermic value from the electrostatic attraction and hydrophobic interaction is less than the endothermic value from the destroyed of hydrated layer structure and the change of secondary structure of BSA. When the concentration of surfactant in the cell is higher than CMC, the surfactant micelles is formed, and the electrostatic attraction is weakened. The interaction enthalpy between surfactants and BSA becomes stable at certain concentrations of surfactants.

\section{Conclusions}

In this manuscript, the interactions between three kinds of quaternary ammonium cationic surfactants with different lengths of alkyl chains $\left(\mathrm{C}_{12}, \mathrm{C}_{14}\right.$ and $\left.\mathrm{C}_{16}\right)$ in the Tris- $\mathrm{HCl}$ buffer solution ( $\mathrm{pH}=7.0$ ) with BSA have been investigated by UV-Vis, FL, DLS and ITC. The results showed that the conformation of BSA is changed by the addition of surfactants, and the increase of alkyl chain length of surfactant is beneficial to the binding of BSA. Three quaternary ammonium cationic surfactants have the static quenching effect on the intrinsic fluorescence of BSA and the maximum emission wavelength of BSA occurs blue shift. In the cases of solutions with low surfactant concentrations, the particle size of surfactants-BSA systems is increased with the increase of alkyl chain length of surfactants. While in concentrated surfactant solutions, surfactant is able to destroy the secondary structure of BSA. ITC results indicated that the main force types of interactions between BSA and three surfactants at low concentrations are hydrophobic and electrostatic interactions, and surfactants with long alkyl chain interact with BSA completely at very low concentrations without the break of the secondary structure of BSA.

The results of interaction between BSA and DHDAB, THDAB, CHDAB are similar to the interaction between BSA and traditional quaternary ammonium cationic surfactants: dodecyltrimethylammonium bromide (DTAB), tetradecyltrimethylammonium bromide (TTAB), and cetyltrimethylammonium bromide (CTAB). While, since the existence of $-\mathrm{OH}$ group, the electrostatic interaction between DHDAB, THDAB, CHDAB and BSA is stronger than the electrostatic interaction between DTAB, TTAB, CTAB and BSA ${ }^{51}$.

Supporting Information: The infrared spectra, NMR, EA and TG-DTG curves of DHDAB, THDAB and CHDAB have been included. This information is available free of charge via the internet at http://www.whxb.pku.edu.cn.

\section{References}

(1) Fainerman, V. B.; Zholob, S. A.; Leser, M.; Michel, M.; Miller, R. J. Colloid Interface Sci. 2004, 274, 496. doi: 10.1016/j. jcis.2003.12.057

(2) Gull, N.; Chodankar, S.; Aswal, V. K.; Sen, P.; Khan, R. H. Colloids Surf. B: Biointerfaces 2009, 69, 122. doi: 10.1016/j. colsurfb.2008.11.009

(3) Mehta, S. K.; Bhasin, K. K.; Kumar, A. Colloids Surf. A: Physicochem. Eng. Aspects 2009, 346, 195. doi: 10.1016/j. colsurfa.2009.06.016

(4) Turro, N. J.; Lei, X. G.; Ananthapadmanabhan, K. P.; Aronson, M. Langmuir 1995, 11, 2525. doi: 10.1021/la00007a035

(5) Mehan, S.; Aswal, V. K.; Kohlbrecher, J. Langmuir 2014, 30, 9941. doi: 10.1021/1a502410v

(6) Mackie, A.; Wilde, P. Adv. Colloid Interface Sci. 2005, 117, 3. doi: 10.1016/j.cis.2005.04.002

(7) Chi, E. Y.; Krishnan, S.; Randolph, T. W.; Carpenter, J. F. Pharm. Res. 2003, 20, 1325. doi: 10.1023/A:1025771421906

(8) De, S.; Girigoswami, A.; Das, S. J. Colloid Interface Sci. 2005, 285, 562. doi: 10.1016/j.jcis.2004.12.022

(9) Miller, R.; Fainerman, V. B.; Makievski, A. V.; Krägel, J.; Grigoriev, D. O.; Kazakov, V. N.; Sinyachenko, O. V. Adv. Colloid Interface Sci. 2000, 86, 39. doi: 10.1016/S0001-8686 (00)00032-4

(10) Coke, M.; Wilde, P. J.; Russell, E. J.; Clark, D. C. J. Colloid Interface Sci. 1990, 138, 489. doi: 10.1016/0021-9797(90) 90231-C

(11) McCormack, F. X.; King, T. E., Jr.; Voelker, D. R.; Robinson, P. C.; Mason, R. J. American Review of Respiratory Disease 1991, 144, 160. doi: 10.1164/ajrccm/ 144.1.160

(12) Bordbar, A. K.; Taheri-Kafrani, A. Colloids Surf. B: Biointerfaces 2007, 55, 84. doi: 10.1016/j.colsurfb.2006.11.012

(13) Wang, Y.; Guo, R.; Xi, J. J. Colloid Interface Sci. 2009, 331, 470. doi: 10.1016/ j.jcis.2008.12.020

(14) Gelamo, E. L.; Tabak, M. Spectrochim. Acta. A 2000, 56, 2255. doi: 10.1016/ S1386-1425(00)00313-9

(15) Kwaambwa, H. M.; Maikokera, R. Colloids Surf. B Biointerfaces 2008, 64, 118. doi: 10.1016/j.colsurfb.2008.01.014

(16) Klajnert, B.; Bryszewska, M. Bioelectrochemistry 2002, 55, 33. doi: 10.1016/S1567-5394(01)00170-0

(17) Carvalho, C. M. L.; Cabral, J. M. S. Biochimie 2000, 82, 1063. doi: 10.1016/S0300-9084(00)01187-1

(18) Rozema, D.; Gellman, S. H. J. Am. Chem. Soc. 1995, 117, 2373. doi: $10.1021 / \mathrm{ja} 00113 \mathrm{a} 036$

(19) Al-Shakhshir, R. H.; Regnier, F. E.; White, J. L.; Hem, S. L. Vaccine 1995, 13, 41. doi: 10.1016/0264-410X(95)80009-3

(20) Ahmad, A. L.; Hairul, N. A. H. Sep. Purif. Technol. 2009, 66, 273. doi: 10.1016/ j.seppur.2008.12.027

(21) Gentili, P. L.; Ortica, F.; Favaro, G. J. Phys. Chem. B 2008, 112, 16793. doi: $10.1021 / \mathrm{jp} 805922 \mathrm{~g}$

(22) Deep, S.; Ahluwalia, J. C. Phys. Chem. Chem. Phys. 2001, 3, 
4583. doi: 10.1039/ B105779K

(23) Madaeni, S. S.; Rostami, E. Chem. Eng. Technol. 2008, 31, 1265. doi: $10.1002 /$ ceat.200700496

(24) Zhao, L.; Liu, R.; Zhao, X.; Yang, B.; Gao, C.; Hao, X.; Wu, Y. Sci. Total. Environ. 2009, 47, 5019. doi: 10.1016/j. scitotenv.2009.05.052

(25) Reynolds, J. A.; Herbert, S.; Polet, H.; Steinhardt, J Biochemistry 1967, 6, 937. doi: 10.1021/bi00855a038

(26) Mehta, S. K.; Bhasin, K. K.; Kumar, A. J. Colloid Interface Sci. 2008, 323, 426. doi: 10.1016/j.jcis.2008.04.026

(27) Lissi, E.; Abuin, E.; Lanio, M. E.; Alvarez, C. J. Biochem. Biophys. Methods 2002, 50, 261. doi: 10.1016/S0165-022X(01) 00237-8

(28) Wang, Y. Q.; Zhang, H. M.; Zhang, G. C.; Tao, W. H.; Tang, S. H. J. Lumin. 2007, 126, 211. doi: 10.1016/j.jlumin.2006.06.013

(29) Gauthier, T. D.; Shane, E. C.; Guerin, W. F.; Seitz, W. R.; Grant, C. L. Environ. Sci. Technol. 1986, 20, 1162. doi: 10.1021/ es00153a012

(30) Marras, S. A.; Kramer, F. R.; Tyagi, S. Nucleic. Acids. Res. 2002, 30, 122. doi: 10.1093/nar/gnf121

(31) Fraiji, L. K.; Hayes, D. M.; Werner, T. C. J. Chem. Educ. 1992, 69, 424. doi: 10.1021/ed069p424

(32) Lakowicz, J. R.; Weber, G. Biochemistry 1973, 12, 416. doi: 10.1021/ed069p424

(33) Gray, J. J. Curr. Opin. Struc. Biol. 2004, 14, 110. doi: 10.1016/j. sbi.2003.12.001

(34) Seetharamappa, J.; Kamat, B. P. Chem. Pharm. Bul. 2004, 52, 1053. doi: $10.1248 / \mathrm{cpb} .52 .10531$

(35) Eftink, M. R.; Ghiron, C. A. Anal. Biochem. 1981, 114, 199. doi: 10.1016/0003-2697(81)90474-7

(36) Ware, W. R. J. Phys. Chem. 1962, 66, 455. doi: 10.1021/ j100809a020

(37) Papadopoulou, A.; Green, R. J.; Frazier, R. A. J. Agric. Food. Chem. 2005, 53, 158. doi: 10.1021/jf048693g

(38) Barik, A.; Priyadarsini, K. I.; Mohan, H. Photochem. Photobiol.
2003, 77, 597. doi: 10.1562/0031-8655(2003)077<0597: PSOBOC $>2.0 . \mathrm{CO} ; 2$

(39) Congdon, R. W.; Muth, G. W.; Splittgerber, A. G. Anal. Biochem. 1993, 213, 407. doi: 10.1006/abio.1993.1439

(40) Martin, V. I.; Rodriguez, A.; Maestre, A.; Moya, M. L. Langmuir 2013, 29, 7629. doi: 10.1021/la400789k

(41) Zhang, Y. Z.; Zhou, B.; Liu, Y. X.; Zhou, C. X.; Ding, X. L.; Liu, Y. J. Fluoresc. 2008, 18, 109. doi: 10.1007/s10895-0070247-4

(42) Hu, Y. J.; Liu, Y.; Jiang, W.; Zhao, R. M.; Qu, S. S. J. Photochem. Photobiol. B. 2005, 80, 235. doi: 10.1016/j. jphotobiol.2005.04.005

(43) Zhou, T.; Ao, M.; Xu, G.; Liu, T.; Zhang, J. J. Colloid Interface Sci. 2012, 389, 175. doi: 10.1016/j.jcis.2012.08.067

(44) Ojha, B.; Das, G. Chem. Phys. Lipids 2011, 164, 144. doi: 10.1016/ j.chemphyslip.2010.12.004

(45) Jaiswal, S.; Mondal, R.; Paul, D.; Mukherjee, S. Chem. Phys. Lett. 2016, 646, 18. doi: 10.1016/j.cplett.2015.12.051

(46) Różycka-Roszak, B.; Woźniak, E.; Misiak, P.; Frąckowiak, R.; Wilk, K. A. J. Chem. Thermodyn. 2013, 66, 1. doi: org/10.1016/j. jet.2013.06.012

(47) Covis, R.; Vives, T.; Gaillard, C.; Benoit, M.; Benvegnu, T. Carbohydrate Polymers 2015, 121, 436. doi: 10.1016/j. carbpol.2015.01.001

(48) Xiang, J.; Fan, J. B.; Chen, N.; Chen, J.; Liang, Y. Colloids Surf. B: Biointerf. 2006, 49, 175. doi: 10.1016/j.colsurfb.2006.03.015

(49) Asker, D.; Weiss, J.; McClements, D. J. Langmuir 2009, 25, 116. doi: $10.1021 / 1 \mathrm{a} 803038 \mathrm{w}$

(50) Bordbar, A. K.; Taheri-Kafrani, A.; Mousavi, H. A.; Haertle, T. Arch. Biochem. Biophys. 2008, 470, 103. doi: 10.1016/j. abb.2007.11.015

(51) Misra, P. K.; Dash, U.; Maharana, S. Colloids Surf. A: Physicochem. Eng. Aspects 2015, 483, 36. doi: 10.1016/j.colsurfa.2015.06.052 
Supporting Information for Acta Phys. -Chim. Sin. 2016, 32 (12), 2951-2960

doi : $\quad$ 10. 3866/PKU. WHXB201609231

\title{
季铵盐型阳离子表面活性剂与牛血清白蛋白的相互作用
}

\author{
谢湖均 ${ }^{1, *} \quad$ 刘程程 $^{1}$ 孙 强 ${ }^{1} \quad$ 顾青 ${ }^{2, *}$ 雷群芳 $^{3}$ \\ 方文军 ${ }^{3, *}$ \\ ( ${ }^{1}$ 浙江工商大学应用化学系, 杭州 $310018 ;{ }^{2}$ 浙江工商大学食品与生物工程学院, 杭州 310018 ; \\ 3 浙江大学化学系, 杭州 310028)
}

\section{The Interactions between Quaternary Ammonium Cationic Surfactants and Bovine Serum Albumin}

\author{
XIE Hu-Jun ${ }^{1, *} \quad$ LIU Cheng-Cheng ${ }^{1} \quad$ SUN Qiang $^{1} \quad$ GU Qing ${ }^{2, *}$ \\ LEI Qun-Fang ${ }^{3}$ FANG Wen-Jun ${ }^{3, *}$ \\ ( ${ }^{1}$ Department of Applied Chemistry, Zhejiang Gongshang University, Hangzhou 310018, P. R. China; \\ ${ }^{2}$ School of Food Science and Biotechnology, Zhejiang Gongshang University, Hangzhou 310018, P. R. China; \\ ${ }^{3}$ Department of Chemistry, Zhejiang University, Hangzhou 310028, P. R. China)
}

${ }^{*}$ Corresponding authors. XIE Hu-Jun, Email: hujunxie@gmail.com; Tel: +86-571-28008974.

FANGWen-Jun, Email: fwjun@zju.edu.cn.

GU Qing, Email: guqing2002@ hotamail.com.. 

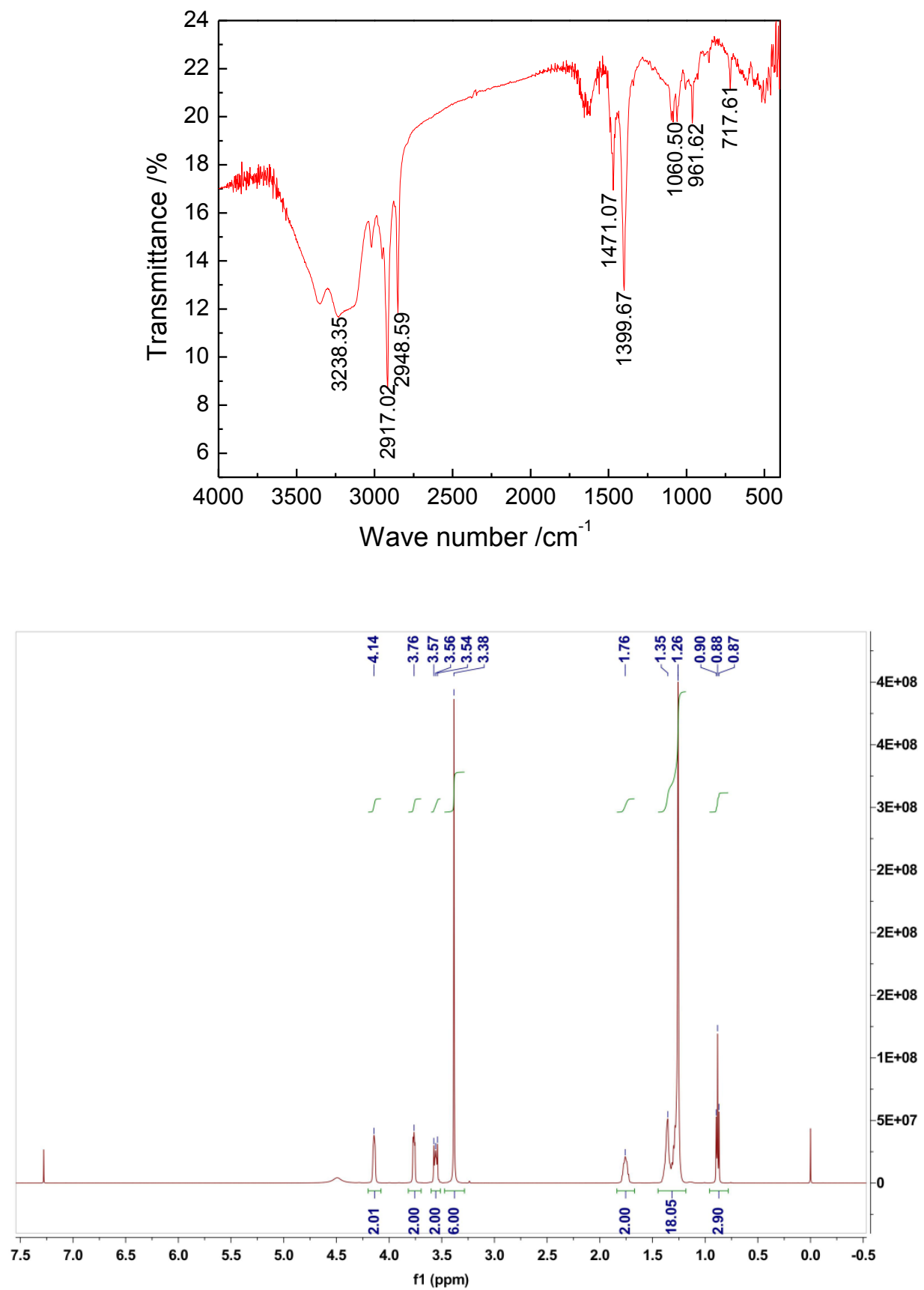

Fig.S1 Infrared and NMR spectra of DHDAB 
Table S1 Elemental analysis (\%) of DHDAB

\begin{tabular}{cccc}
\hline & $\mathrm{N}$ & $\mathrm{C}$ & $\mathrm{H}$ \\
\hline theoretical value & 4.14 & 56.80 & 10.72 \\
actual value & 4.15 & 56.73 & 10.77 \\
\hline
\end{tabular}
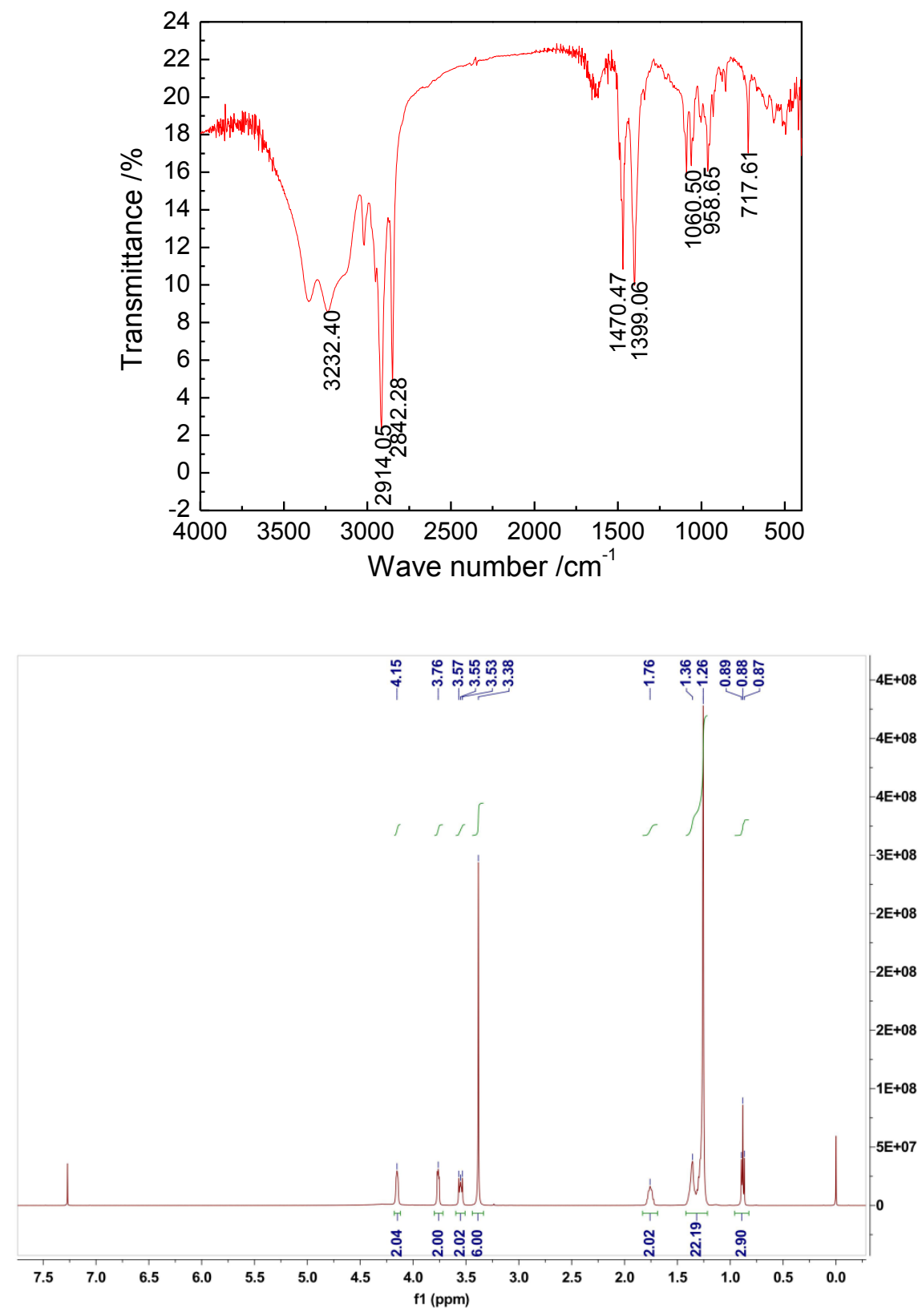

Fig.S2 Infrared and NMR spectra of THDAB 
Table S2 Elemental analysis (\%) of THDAB

\begin{tabular}{cccc}
\hline & $\mathrm{N}$ & $\mathrm{C}$ & $\mathrm{H}$ \\
\hline theoretical value & 3.82 & 59.00 & 11.00 \\
actual value & 3.85 & 59.24 & 11.13 \\
\hline
\end{tabular}
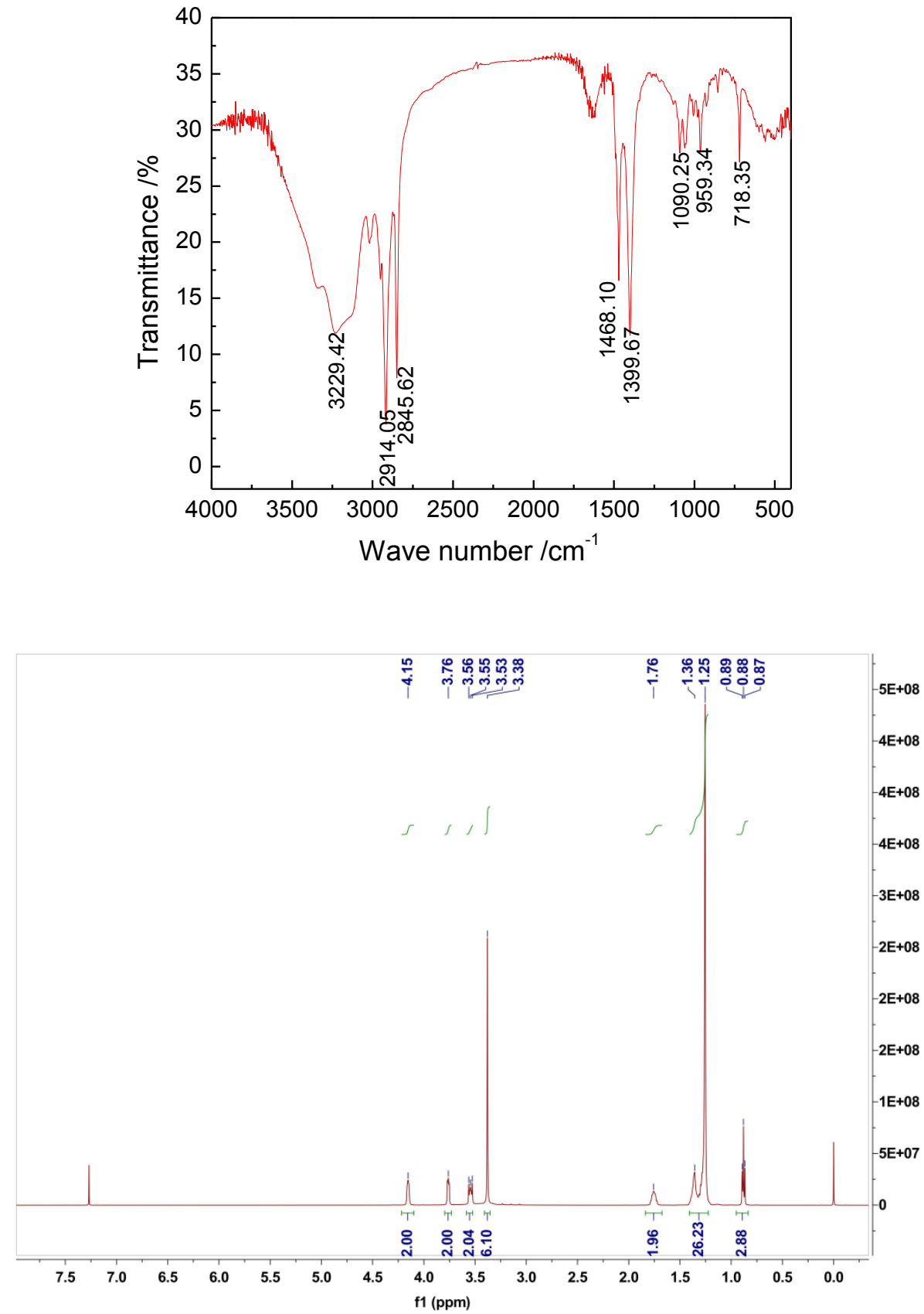

Fig.S3 Infrared and NMR spectra of CHDAB 
Table S3 Elemental analysis (\%) of CHDAB

\begin{tabular}{cccc}
\hline & $\mathrm{N}$ & $\mathrm{C}$ & $\mathrm{H}$ \\
\hline theoretical value & 3.55 & 60.90 & 11.24 \\
actual value & 3.51 & 61.03 & 11.55 \\
\hline
\end{tabular}

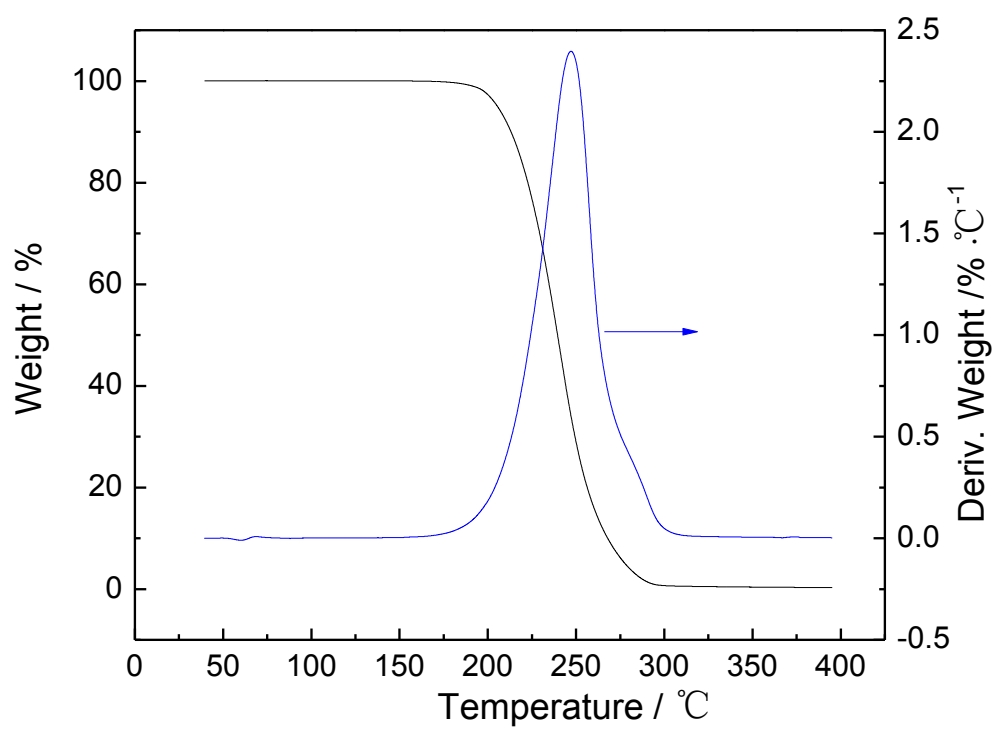

Fig.S4 TG-DTG curves of DHDAB·

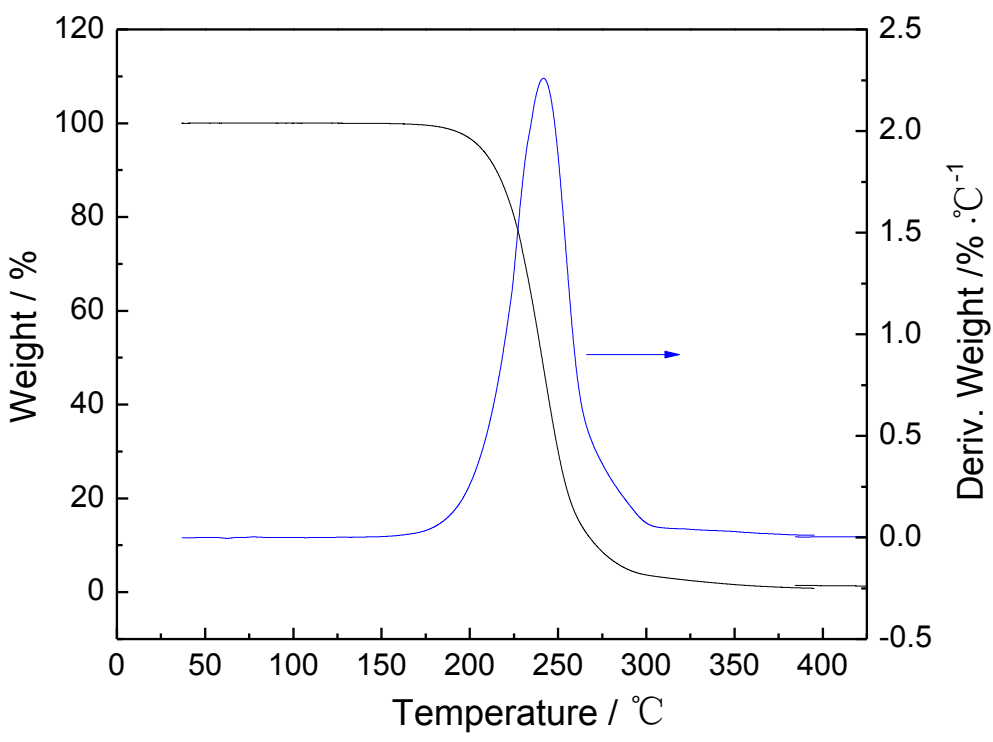

Fig.S5 TG-DTG curves of THDAB 


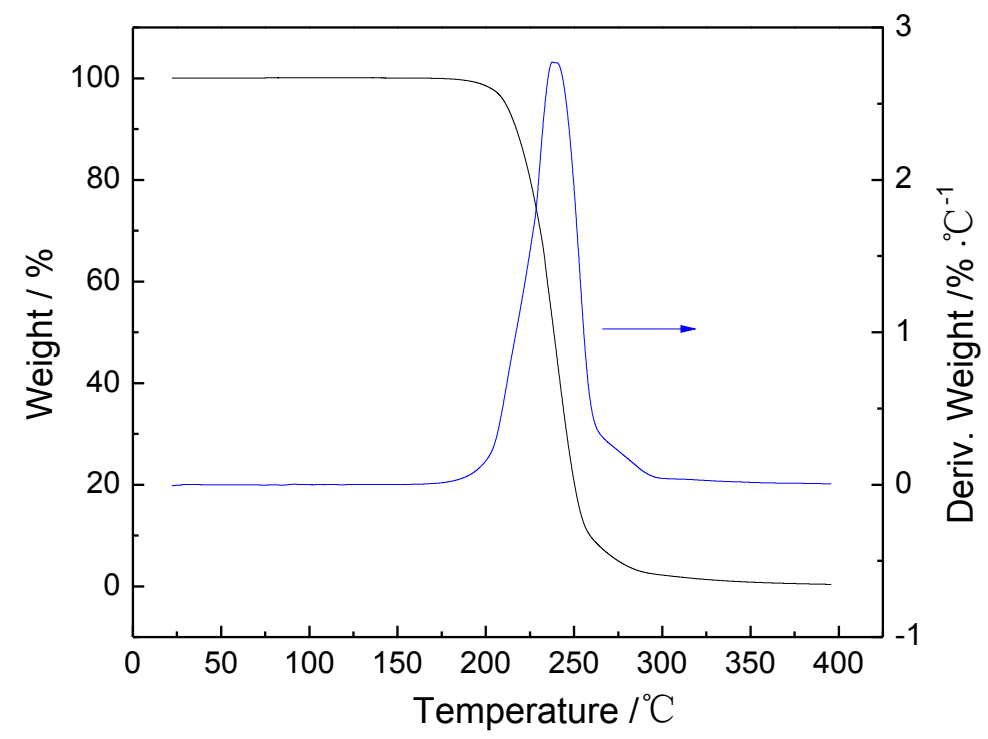

Fig.S6 TG-DTG curves of CHDAB 